\title{
CLAIMS FOR PSYCHIATRIC INJURY IN THE WORKPLACE: AN ANALYSIS UNDER THE LAW OF NEGLIGENCE AND THE ISLAMIC PERSPECTIVE
}

\author{
Mushera Bibi Ambaras Khan* \\ Farheen Baig Sardar Baig** \\ Haniza Rais***
}

\begin{abstract}
In recent years, claims for damages for deliberately or negligently inflicted psychiatric illness have succeeded against employers in jurisdictions outside Malaysia. In the case of Mount Isa Mines v Pusey, the court decided that an employer's duty of care towards the employees is not limited to cases of physical injury but also extended to cases of psychiatric injury. In order to claim damages for psychiatric injury, the law of torts requires the plaintiff to prove two elements: namely, reasonable foreseeability and proximity. This paper examines on the two elements as required under the law in the context of psychiatric illness in the workplace. The paper analyses cases from the UK, Malaysia and Australia, elaborating on how an employee can successfully bring an action against his/her employer for his/her psychiatric illness suffered at the workplace. The author employs doctrinal analysis from primary and secondary legal sources in arriving at the solutions to the above problem. This paper will significantly contribute to the existing literature by discussing the challenges faced by an employee in proving the conditions required by the law and its solutions to ensure that employee who suffered psychiatric illness or injury in the workplace has a redress under the law of negligence. This paper also considers the scenario from an Islamic perspective in order to shed light on the seriousness of the welfare of employee guaranteed by the religion. Having shown how
\end{abstract}

* Professor, Department of Civil Law, Ahmad Ibrahim Kulliyyah of Laws, International Islamic University Malaysia. Email: mushera@iium.edu.my.

** Professor, Department of Legal Practice, Ahmad Ibrahim Kulliyyah of Laws, International Islamic University Malaysia. Email: farheenb@iium.edu.my.

*** Associate Professor, Kulliyyah of Education, International Islamic University Malaysia. Email: hanrais@iium.edu.my. 
divine revelation makes it incumbent on an employer to honour and respect his worker, and treat him in kindness, it will be further shown how two Court of Appeal decisions have paved the way to find employers negligent for causing distress to their employees' mental health. This paper, thus illustrates yet another fine example of harmonisation between the two systems of law, that can come together to achieve the same end.

Keywords: $\quad$ Psychiatric illness, employee, law of negligence, Islamic principles, wellness.

\title{
TUNTUTAN BAGI MASALAH PENYAKIT PSIKIATRI DI TEMPAT KERJA: ANALISIS DI BAWAH UNDANG-UNDANG KECUAIAN DAN PANDANGAN ISLAM
}

\begin{abstract}
ABSTRAK
Akhir-akhir ini mahkamah di luar Malaysia telah membenarkan gantirugi berkaitan masalah psikiatri yang disebabkan kecuaian atau salah laku majikan. Dalam kes Mount Isa Mines lwn Pusey, Mahkamah telah memutuskan bahawa kewajipan berhati-hati atau tanggungjawab berhati-hati (duty of care) oleh majikan kepada pekerjanya tidak terhad kepada kes-kes kecederaan fizikal sahaja malah juga meliputi masalah psikiatri. Dalam undang-undang tort, dua elemen perlu dibuktikan oleh plaintif untuk menuntut ganti rugi bagi masalah psikiatri iaitu: jangkaan yang munasabah (reasonable foreseability) dan kedekatan (proximity). Artikel ini mengkaji dua elemen yang diperlukan di bawah undangundang dalam konteks masalah psikiatri di tempat kerja. Artikel ini juga menganalisa kes-kes dari UK, Malaysia dan Australia, dan menghuraikan bagaimana seorang pekerja berjaya untuk membawa tindakan undang-undang terhadap majikannya disebabkan oleh masalah psikiatri yang ditanggung di tempat kerja. Penulis menggunakan analisis doktrin dari sumber undang-undang primer dan sekunder bagi mencapai solusi untuk isu-isu yang dibangkitkan di atas. Artikel ini akan memberi sumbangan besar dan ketara kepada kajian yang sedia ada dengan membincangkan cabaran-cabaran yang dihadapi oleh seorang pekerja untukmembuktikan elemen-elemen yang diperlukan oleh undangundang dan cara penyelesaian untuk memastikan bahawa pekerja yang menghidapi penyakit atau masalah psikiatri di tempat kerja mendapat ganti rugi di bawah undang-undang kecuaian. Artikel ini juga meninjau pandangan Islam mengenai hal-hal berkaitan kebajikan pekerja untuk mengetahui sejauh mana Islam memandang isu kepentingan menjaga kemaslahatan dan kebajikan pekerja. Selain penekanan wahyu yang
\end{abstract}


menggalakkan majikan supaya menghormati dan melayani pekerja dengan baik, dua keputusan Mahkamah Rayuan juga dirujuk dalam artikel ini yang mendapati bahawa majikan telah cuai kerana menyebabkan tekanan kepada kesihatan mental pekerja mereka. . Artikel ini sekaligus menggambarkan satu lagi contoh pengharmonian yang baik di antara kedua-dua sistem undang-undang, yang boleh bersatu untuk mencapai matlamat yang sama.

Kata kunci: Masalah psikiatri, pekerja, undang-undang kecuaian, prinsip Islam, kesejahteraan.

\section{Introduction}

The public usually sympathizes with victims with broken bones rather than those with broken minds. Those suffering from physical ailments can get the illness diagnosed and treated. The advancement in medical fields, including the administration of antibiotics and vaccination, has enable persons with physical illness to battle viruses and diseases. Psychiatric injury, on the other hand has not received proper attention for many years. A recognizable psychiatric injury is a serious illness which affects the life of a person much more than physical injuries. Psychiatric injury has a direct relation with the condition in the autonomic nervous system in a person's body.

Psychiatric injury or illness, previously known as nervous shock can be traced to the early $20^{\text {th }}$ century. In the early days, the claimant has to prove that the illness suffered had been induced by 'shock' experienced by the claimant. 'Shock' has been defined as the "sudden appreciation by sight or sound of a horrifying event, which violently agitates the mind". ${ }^{1}$ Psychiatric injury which is the result of emotional distress goes beyond simple grief, upset or unhappiness. Depression, phobic anxiety, neuroses and post-traumatic stress disorder are common examples of psychiatric injuries that are diagnosed by medical experts; namely, psychiatrists and clinical psychologists.

A few decades ago, those who suffered from psychiatric injury were not aware of the seriousness and implications of their mental health condition nor did they anticipate a legal claim against the negligent party who caused the psychiatric injury. Prior to the formulation of a proper yardstick to measure and determine psychiatric

1 Alcock v Chief Constable South Yorkshire Police, 1 AC. 310, (1992), 401. 
injury, people who sustained psychological harm might not have considered legal action..$^{2}$ It was not until 1888 that the first case reached the court; at that time 'nervous shock' was a more popular term. Psychiatric injury is sometimes described as a 'grey area' of negligence because judicial attitudes are constantly developing and new formulations of the scope of the duty of care are regularly produced. ${ }^{3}$

Today, the classification of mental disorders recommended by the World Health Organization is a part of international classification. The diagnostic criteria are also laid out clearly. Currently, the most commonly used tools include the American Diagnostic and Statistical Manual of Mental Disorder (DSM-5) and the World Health Organisation's ICD-10 Classification of Mental and Behavioural Disorders (1992). ${ }^{4}$ With a clearer yardstick on measuring mental health, victims of psychiatric injury will find it possible to get redress under the law. In order to have a successful claim in psychiatric injury, the claimant must be able to tender medical evidence. With the advancement of knowledge in this area of medical and the availability of the tools in the diagnosis of psychiatric injury, psychiatrists are now well aware of the condition of the claimants and are able to provide medical evidence to confirm the presence of such injury.

A positive development in the area of claim relating to psychiatric injury is vital especially at current time. A survey conducted in 2019 in Malaysia found that Malaysian employees are overworked, sleep deprived, with 51 per cent suffering from at least one dimension of work-related stress. ${ }^{5}$

2 Vivienne Harpwood, Modern Tort Law (London:Routledge-Cavendish, 2008), 38. It is worth noting that the Diagnostic and Statistical Manual of Mental Disorders (DSM-1) was approved in 1951 and first published in 1952.

3 Harpwood, 2 Modern Tort Law, 36.

4 Butler and Desmond,"Psychiatric injury in the workplace: Direction for cases involving Stress or bullying,"Torts Law journal14, no.2(2006):124134.

5 B. Suresh Ram, "Survey: Malaysian employees are overworked, sleep deprived, unhealthy," New Straits Times,November 15, 2019, accessed October 2 , 2021 https://www.nst.com.my/news/nation/2019/11/539026/surveymalaysian-employees-are-overworked-sleep-deprived-unhealthy. 
Survey on Malaysia's Healthiest Workplace by AIA Vitality 2019 revealed that mental health problems continue to be on the rise with 22 per cent of employees reporting that they had a lot of financial concerns at present. ${ }^{6}$ The Covid-19 pandemic that hits Malaysia has increased the burden on employees living in the age of digital and ecommunications and may contribute as an accelerating factor for stress and psychiatric injury. Mental health problem is related to depression, anxiety and stress. Global surveys found that $53 \%$ of workers are experiencing rising level of stress while 59\% attributes their stress to their job. ${ }^{7}$ In Malaysia, mental health issues are one of the major problems. According to the National Health and Morbidity Survey 2019, about half a million people are suffering from depression among Malaysian adults. ${ }^{8}$

Despite the various laws which provide protection against physical harm to the employees, Malaysia lacks specific laws on protection against infliction of psychological harm arising from the negligence of the employer. Unlike Malaysia, employees in Australia and United Kingdom thrive in their claims against their employers for psychiatric injury arising from the employer's negligence. This paper attempts to revisit the law on psychiatric injury in the workplace under the law of negligence and under Islamic principles.

\section{Development of the law on psychiatric injury under the law of torts}

The law does not furnish remedy in every case of injury. In the sphere of the law of tort in negligence, in order for the claimant to succeed, he

6 Ram, "Survey: Malaysian employees are overworked".

7 Ophelia Yeung and Katherine Johnston. The Future of Wellness at Work. Research report, Global Wellness Institute,2016, accessed October2021,http://static1.squarespace.com/static/54306a8ee4b07ea66e a32cc0/t/57b5a1961b631bc09935c73d/1471521178364/GWI-TheFuture-of-Wellnessat-Work2016.pdf?inf contact key=146766f71a8b7cd53dd8c0ab8953fce65e4d5 $233157 \mathrm{fc} 8 \mathrm{cad}-\overline{\mathrm{d}} 43 \mathrm{~b} 34 \overline{\mathrm{b}} 02 \mathrm{fd} 4 \mathrm{c} 86$.

8 Institute for Public Health 2020. National Health and Morbidity Survey (NHMS) 2019:

Non-communicable diseases, healthcare demand, and health literacyKey Findings,2020 accessed October 2021. https://iptk.moh.gov.my/images/technical_report/2020/4_Infographic_B ooklet_NHMS_2019_-_English.pdf. 
must be able to prove that there is a duty of care owed to him or her by the negligent party. When deciding on the existence of duty of care, the courts are confronted with issues which are inherently policy in nature. The tort of negligence preceded the seminal case of Donoghue $v$ Stevenson. The later decisions of the courts in the tort of psychiatric injury cases reflect the changing attitudes of the courts and the society towards psychiatric injury.

The first attempt to claim damages for psychiatric injury was in Victorian Rly Comrs $v$ Coultas. ${ }^{9}$ The claim failed due to the Privy Council's reluctance to hold the appellant liable for damages arising from mere sudden terror when it was unaccompanied by any physical injury. One can argue that their Lordships' hesitance could be due to the unavailability of medical evidence to assist them in deciding cases on psychiatric injury.

The first successful claim involving psychiatric injury, previously known as nervous shock, involving primary victim in England was the case of Dulieu $v$ White \& Sons. ${ }^{10}$ The claimant, a pregnant lady suffered psychiatric injury when a van driven negligently by the defendant crashed to the window of the bar where she was working. The mental distress she suffered resulted in her giving birth prematurely nine days after the incident. Kennedy J however observed that the court should be careful in entertaining the claim for psychiatric injury so as to restrict the scope of liability for nervous shock. ${ }^{11}$ Despite the cautious approach taken by the court in restricting the scope of liability when dealing with psychiatric injury cases, the court was willing to allow a claim for psychiatric injury arising from a reasonable fear of immediate personal injury to oneself, marking a progress in the claim by psychiatric injury victims. Two decades later in Hambrook $v$ Stokes Bros ${ }^{12}$, there was positive judicial attitude towards victims who suffered from psychiatric injury, arising from fear for the safety of close relatives, currently known as secondary victim.

In Bourhill $v$ Young ${ }^{13}$, a claim in psychiatric injury was considered by the House of Lords. This classic Scottish case, the

\footnotetext{
9 (1888) 13 App Cas 222.

10 (1901) 2 KB 669

11 (1901) 2 KB 669

12 1925) $1 \mathrm{~KB} 141$.

13 (1943) AC 92.
} 
claimant who had just alighted from a tram, heard the impact from an accident 50 yards away on the other side of the road. She later went to the place of the scene and suffered nervous shock as a result of what she saw. She gave birth to a still-born child very soon afterwards, but her claim for nervous shock failed. The House of Lords held that she was outside the area of impact and the test was that of foresight of shock. The court subsequently received more cases on secondary victim liability including the case of McLoughlin $v$ O'Brian in the House of Lords in 1982. The scope of liability keeps expanding with subsequent decisions including Karlj v McGrath ${ }^{14}$ where the claimant who suffered nervous shock when she saw the dreadful condition of her child who was the victim of negligent delivery by a doctor succeeded in her action.

As will be discussed in this paper, the courts around the world are less hesitant when attending to cases involving psychiatric injury suffered by employees at workplace arising from the negligence of the employer. However, with the increasing number of cases of employees suffering from psychiatric injury arising from the negligence of the employers, the court has abandoned the requirement of "shock" and allowed claims by employees under "psychiatric injury" or psychiatric illness.

\section{The Origin of Psychiatric Injury under the Law of Negligence}

The law pertaining to psychiatric injury owes its modern existence to the law of negligence. The claimant must establish that the negligence on the part of the defendant has led to the claimant suffering from psychiatric injury.

Under the law of negligence, the claimant must prove three elements. First, the claimant must establish that the negligent party owes the claimant a duty of care. The main purpose of duty of care is to link the claimant and the defendant in a legal relationship. The concept of duty of care is a very important control mechanism in restricting the defendant's liability for the tort of negligence. A lack of duty of care will precludes defendant's liability in negligence. Second, the claimant needs to prove that there is a breach of the duty of care owed to him. The relevant question here is to ask whether the conduct

14 (1986) 1 All ER 907. 
of the defendant fell below the standard of care which the law expects of the defendant. Fixing the requisite reasonable standard of care in any given case is a question of law. Thirdly, the claimant has to establish that he suffered the damage as a result of that breach of duty of care.

The Caparo test emerged from the House of Lords decision in Caparo Industries Plc v Dickman. ${ }^{15}$ In some scenarios, a duty of care will be presumed where the claimant can align his scenario with one of the recognisable or the traditional categories of duty of care. An employer-employee relationship is an example of the recognised category. As a general rule, all employers have a duty to take reasonable care for the safety of their employees. However, where employees suffered from psychiatric harm or injury which arises as a result of the employer's negligence, the English courts' approach in determining the liability of the employer slightly differ from early Australian courts decisions. In principle, when determining the liability of the negligent party in cases of psychiatric injury, the English courts will classify the plaintiff into 'primary' and 'secondary' victims.

In a notable case of Mount Isa Mines Ltd v Pusey ${ }^{16}$ in Australia, the court observed that "an employer's duty of care to its employee is not only limited to physical injury but also extended to cases of psychiatric injury" without making any distinction between primary and secondary victims. In Hale $v$ London Underground, ${ }^{17}$ a fireman who had been involved in the rescue of the victims of the serious fire at King's Cross Underground Station successfully claimed for psychiatric injury. The claimant, Hale experienced nightmares about dead people and skeletons, severe depression which had almost led to the breakdown of his marriage and he had only been able to manage a desk job since returning to work. He was unlikely able to continue working and the court concluded that he would continue to suffer from a deep-rooted depression which is unlikely to abate. ${ }^{18}$

Having established the duty of care, the court will examine whether the second element, the breach of duty, exists. Psychiatric injury, being the generic of the law of negligence, requires that the damage must be of a foreseeable kind. What is required in psychiatric

$\begin{array}{ll}15 & \text { [1990] } 2 \text { AC } 605(\mathrm{HL}) . \\ 16 & \text { (1970) 125 CLR 383. } \\ 17 & \text { (1992) 11 BMLR 81. } \\ 18 & \text { (1992) 11 BMLR 81. }\end{array}$


injury cases is foreseeability of psychiatric injury. ${ }^{19}$ This has been applied in subsequent cases on psychiatric injury including the case of Jaensch $v$ Coffey. ${ }^{20}$

\section{Primary victim}

In the English case, Page $v$ Smith, ${ }^{21}$ the House of Lords drew a distinction between cases involving primary and secondary victims. The law imposes a less onerous test on primary victims those who are "directly involved in the accident, and well within the range of foreseeable physical injury". ${ }^{22}$ In such cases, foreseeability of any form of physical injury is enough to establish a duty of care; thus, allowing a claimant to bring action for psychiatric injury as well.

\section{Secondary victim}

In the other category of case, namely the secondary victim case, where the plaintiff is a witness of injuries caused to others, it is essential to show that psychiatric injury is foreseeable. The Australian court's decision differs from the English courts' approach. The Australian courts refused the importation of Page $v$ Smith doctrine into Australian law. Cases analysis reflects that the English courts have adopted much tighter limitations on liability in psychiatric injury as compared to the Australian courts. The Malaysian courts have mainly followed the English courts' approach.

\section{The Current Approach relating to 'Work Stress'}

The earlier cases on psychiatric illness or nervous shock have relied heavily on the element of 'shock' before allowing the claims. However, there has been a shift in the direction of psychiatric illness claims in the recent years. A victim is no more required to prove the element of "shock" in order to succeed in his claim. One could argue that the

\footnotetext{
19 See the decision by the Privy Council in the Wagon Mound (No. 1) [1961], 36.

20 (1984) 54 ALR 417

21 (1996) AC 155.

22 (1996) AC 155.
} 
requirement of 'shock' is based on an out-dated conception of how psychiatric injury occurs.

Important cases are emerging from situations in which the parties are employer and employee. Work stress over prolonged period commonly led to anxiety and depression. More and more employees across the world are struggling with serious emotional health issues. ${ }^{23}$ In an earlier study carried by Workplace Options, a regional breakdown of the analysis shows a significant increase in the number of reported cases dealing with anxiety, depression and stress in all regions of the world. ${ }^{24}$ Asia scored the highest percentage on increase of cases involving depression. ${ }^{25}$

Some jurisdictions, such as the UK and Australia have recognised claims for work stress arising from the negligence of the employers. Actions for psychiatric injury have received serious consideration in cases involving professionals across the board, in private sectors and in governmental bodies.

Since the "sudden shock" element is not required for psychiatric injury cases, employees who suffer psychiatric injury as a result of being stressed at work or being bullied therefore can claim damages in civil claim against their employers. As such, an employer can be held liable for psychiatric injury including cases where the injury is not a result of any sudden traumatic event. There is a growth in cases in this area due to developing understanding in two distinct but inter-related areas of knowledge, namely, psychiatric injury and occupational stress. $^{26}$

23 "Analysis of Global EAP Data Reveals Huge Rise in Depression, Stress, and Anxiety Over Past Three Years," Workplace Options, December 16, 2015, accessed $\quad$ October 2021 https://www.workplaceoptions.com/polls/analysis-of-global-eap-datareveals-huge-rise-in-depression-stress-and-anxiety-over-past-threeyears/.

24 "Analysis of Global EAP Data"

25 "Analysis of Global EAP Data"

26 NJ Mullany and PR Handford, Tort Liability for Psychiatric Damage (Sydney: The Law Book Company Ltd, 1993). 
Work not only offers a secure livelihood but also provides selfaffirmation which, in turn, leads to strengthening self-esteem. ${ }^{27}$ Further, work brings benefits such as long-term social contact, structured daily regimens and most importantly, a feeling of worth making it an important part of social integration. ${ }^{28}$

'Stress' has been defined to mean 'an excess of demands upon an individual in excess of their ability to cope'. ${ }^{29}$ It is however important to note that stress, to a certain level cannot be avoided. Every job comes with certain level of stress; it brings its own set of tasks, responsibilities and day-to-day problems, and the pressures and demands these places have on us are an unavoidable part of working life. However, it is human nature that each person has a certain limit when dealing with pressure. Excessive workplace pressure and the stress to which it can lead can be harmful. 'Stress' is used in the sense of a perceived mismatch between the pressures of the job and the individual's ability to meet them. Work-related stress and poor mental health are cited as major reasons not only for absenteeism but also for occupational disability and for workers seeking early retirement. ${ }^{30}$ Burnout and depression as well as stress related to physical conditions such as high blood pressure, sleeping disorders and low immune system can result in sickness and absence from work. To minimize adverse effects upon the employees, efforts by the employers is needed to protect an individual worker and his or her psychosocial,

27 WHO Regional Office for Europe, and Wolfgang Gaebel, German Alliance for Mental Health. Mental Health and Well-being at The Workplace. Denmark: World Health Organization, 2010, accessed October 05,2021. https://www.euro.who.int/_data/assets/pdf_file/0018/124047/e94345.pd f.

28 "Mental Health and Well-being".

29 Ron Baker and Health Education Authority, Stress in the public sector: nurses, police, social workers and teachers (London: Health Education Authority,1988).

30 WHO Regional Office for Europe, and Wolfgang Gaebel, German Alliance for Mental Health. Mental Health and Well-being at The Workplace. Denmark: World Health Organization, 2010.Accessed October 05,2021.

https://www.euro.who.int/_data/assets/pdf_file/0018/124047/e94345.pd f. 
organizational and physical working environment. ${ }^{31}$ This should be complemented by health promotion activities that aim at improving the individual's coping abilities and strengthening personal skills. ${ }^{32}$

\section{Stressed at Work Claim under Negligence}

\section{Reasonable foreseeability of psychiatric harm}

As mentioned earlier, the first consideration in any negligence claim is whether the claimant was owed a duty of care by the defendant. The concept of duty of care is an essential mechanism in extending or restricting the development of the law of negligence.

The modern approach to deciding whether a duty of care exists in a novel situation is by applying the reasonable foresight test. The claimant must prove that the damage of that type was "reasonably foreseeable". In the context of claim for psychiatric injury, this requires the claimant, as stated in Walker $v$ Northumberland ${ }^{33}$, to establish that the employer knew of the claimant or the employee's tendency to psychiatric injury and took no steps to help. The foresight test derived from Hatton $v$ Sutherland (Court of Appeal) ${ }^{34}$ reaffirmed that the employer's duty of care arises where it was objectively foreseeable that psychiatric injury could foreseeably result from a particular task or tasks.

Closely related to the 'foresight' element is the notion of 'proximity'. This link of proximity arises by virtue of employment relation; however not every employer will be liable for an employee's psychiatric injury. 'Proximity' has proved very essential in determining whether a duty of care exists in relation to psychiatric injury.

Apart from the elements of "foreseeability" and "legal proximity", the claimant will have to establish the rest of the negligence action, which include a breach of the duty and damage resulting from such breach.

\footnotetext{
31 "Mental Health and Well-being at The Workplace".

32 The current trend witness efforts by companies which attempt to provide activities, both physical and spiritual in addressing stress at work.

33 (1995) 1 All ER 737.

34 [2002] EWCA $\underline{\text { Civ }} 76$.
} 
Lady Justice Hale in Hatton $v$ Sutherland ${ }^{35}$ provides importance guidance for cases relating to psychiatric illness involving employees. Employees who are overworked to the point of mental injury is to be permitted to recover damages for the injury on the basis that responsibility for causing psychological risks must be borne by the employer. The threshold question is whether this kind of harm that is, an injury to health which is attributable to stress at work to the employee was reasonably foreseeable. ${ }^{36}$ She acknowledged that mental disorder is harder to foresee than physical injury. An employer is usually entitled to assume that the employee can withstand the normal pressures of the job unless he knows of the vulnerability of the employee.

There are no occupations which may be regarded as intrinsically dangerous to mental health. Hale LJ lists down the factors likely to be relevant in answering whether that particular harm to the employee is foreseeable. The nature and extent of the work by the employee constitute important factors to be considered in answering the above threshold. It is thus relevant to ask whether the workload exceeded the normal workload for that particular job. Further, is the work intellectually or emotionally demanding for the employee? Likewise, it is important to observe whether the demands being made by the employer was unreasonable when compared with the demands made of others in the same or comparable jobs. It is equally relevant to observe whether there is an abnormal level of sickness or absenteeism in the same job or the same department.

Another important factor that the court has to consider, in answering the above threshold, is the signs from the employee of impending harm to health. In other words, the court has to ask whether the employee has a particular vulnerability and whether he has already suffered from illness attributable to stress at work. The employer is entitled to take the information given by his/its employee at face value unless he has good reasons to think to the contrary.

In Melville $v$ Home Office, ${ }^{37}$ the claimant was employed by the defendant as a healthcare officer. His duties included recovering the bodies of prisoners who had committed suicide. He subsequently

\footnotetext{
35 (2004) 1 WLR.

36 (2004) 1 WLR.

37 [2005] EWCA Civ 6133.
} 
suffered from nightmares and flashbacks and developed a stress related illness. Although the claimant gave no indication that he was developing a stress related illness, the defendant's documents recognized that persons who were called on to deal with traumatic incidents in prison including suicides may suffer health problems and that they should receive support from the prison care team. The court awarded the claimant damages for the psychiatric injury. Likewise, in Hiles $v$ South Gloucestershire NHS $v$ Primary Care Trust, ${ }^{38}$ the employee, a health visitor succeeded in her claim against her employer for psychiatric illness she suffered after being given an excessive workload. Her employer was well aware that she was feeling under stress because she had broken down in tears during an appraisal interview. Another successful claim against an employer for foreseeable work-related stress is the case of Green $v$ DP Group Services Ltd (UK). ${ }^{39}$ In this case, the defendant employer was found liable for psychiatric injury suffered by its employee who was known to have been suffering from clinical depression after being bullied by fellow employees.

\section{Breach of duty}

The second consideration for the claimant in a negligence case is to establish that there had been a breach of duty on the part of the defendant. The court has to determine whether the employer has failed to take the steps which are reasonable in the circumstances. An employer falls below the standard of care required resulting in breach of duty of care when it fails to act reasonably in the particular circumstances.

In Hatton $v$ Sutherland the English Court of Appeal established guidelines for judges dealing with claims for negligence against employers in circumstances where claimants' service is terminated due to stress-induced psychiatric illness.

\footnotetext{
38 Unreported 20/12/2006.

39 [2006] EWHC 1898 QB.
} 


\section{"Breakdown" Cases}

In Johnstone $v$ Bloomsbury ${ }^{40}$, a junior doctor had a breakdown after being required to work at the defendant's hospital for excessive hours without rest. His contract of employment provided that he had a standard 40 hour-working week, and in addition he would be available on call for a further 48 hours a week on average. In some weeks he had to work more than 100 hours, with inadequate period of sleep. As a result, he suffered from depression, lethargy, diminished appetite and suicidal feelings. The court held that the employer owed the claimant a duty of care to avoid the foreseeable psychiatric injuries. This duty arises under the law of negligence, irrespective of the contractual terms in the employment contract which required the claimant to work overtime.

In Walker $v$ Northumberland County Council ${ }^{41}$ the claimant, a social worker employed by the defendant, was under an excessive workload and subsequently had a mental breakdown. The nature of the work was inherently very stressful as he was dealing with child abuse cases. He then went on 4 months leave. Upon his return, he had to deal with backlog of cases created whilst he was away plus a considerable new case load, resulting him a second breakdown. The court held that the employer owed him duty of care. When the claimant returned to work after his first breakdown, a repetition of illness was reasonably foreseeable; although the damage may not be foreseeable during the first breakdown he suffered as the claimant was again exposed to the same workload, it was foreseeable to the defendant that claimant will suffer psychiatric injury.

In a case involving a teacher, Barber $v$ Somerset County Council $^{42}$ the claimant sought damages from his employer after suffering a work-related stress breakdown. The claimant's problems began after a restructuring of staffing at the school that meant that he had to take on extra responsibilities in order to maintain his salary level. He had to work longer hours in discharging these new responsibilities. The precise number of work hours ranged from between 61 and 70 hours per week. The claimant first realised that he was not coping well with the additional pressures, finding that he was losing weight,

\footnotetext{
40 (1992) QB 333.

41 (1995) 1 All ER 737.

42 (2004) UKHL 13.
} 
looking drawn, waking up regularly in the night, and having "out of body experiences". ${ }^{43} \mathrm{He}$ mentioned his "work overload" to the deputy head in charge of the timetable. However, it was not until seven months lapsed, when the claimant took three weeks off work with stress and depression. The claimant had several meetings with various members of the school's senior management team upon his return to work, including a meeting with the headmistress, in which he made them aware of the stresses to which he was subject and stated that he felt he was not coping.

At House of Lords, Lord Walker rejected the defendant's argument that:

the school was facing such severe problems (with all the teachers stressed and overworked no budget for more staff', and ... that there was nothing that the school could have done to help ... [the claimant] other than advising him to resign, or in the last resort terminating his employment. ${ }^{44}$

His Lordship thought that the school should have taken the initiative in monitoring the claimant's condition and making some reduction in his workload after it became aware that he felt that he was not coping with the pressures of his new responsibilities. The school thus has failed to take reasonable care of the claimant.

In Maureen Flood $v$ The University Court of the University of Glasgow $^{45}$ the claimant, a senior college lecturer claimed damages for stress related injury suffered as a result of overwork. She was employed from 1999 to 2001 and she had communicated with her managers many times about the overload. She informed her employer that her work overload was affecting her health and causing her to be unable to sleep. She went off work with symptoms that she attributed to her excessive workload and led her to be diagnosed as suffering from a psychiatric injury. Her counsel submitted that the critical feature in this case was the "enormous" workload imposed upon the claimant. Further, the fact that she had communicated of her concern to her line managers point to the fact that the defendant should have been aware that she was working well beyond her normal capacity with the consequent of risk of harm to her. The defendant, in their defense argued that it has a large workforce, with many employees who make complaints. It is very

\footnotetext{
43 (2004) UKHL 13, 47.

44 (2004) UKHL 13, 68.

45 (2008) CSOH 98.
} 
difficult for them to predict whether a particular employee is liable to succumb to psychiatric injury. In this case, the indications were not obvious. The defendant could not have reasonably foreseen that if the pursuer continued to work under the same conditions, she would suffer psychiatric illness. The court was satisfied that there was foreseeability of psychiatric injury, especially considering the fact that the claimant was working over 100 hours a week despite being under contract to do 32.5 hours. The claimant was performing the duties of three former colleagues at the workplace. The fact that the defendant burdened the claimant with excessive workload, in the view of the court, was enough notice to the defendant that they should have taken measures to prevent any damage to the claimant's health.

Dickins $v$ O 2 plc $^{46}$, is another case where the Court of Appeal upheld the decision of a county court to award damages for psychiatric injury due to excessive work related stress. Dickins worked for the defendant, O2 Plc. She had clerical role that included a quarterly audit that she found very stressful. As a result, she began coming into work late on a regular basis. She complained about the stress of her job and asked if she could be moved to a less stressful job, explaining her difficulties. She also requested a 6-month sabbatical. Her employer did not grant this and advised her to contact the $\mathrm{O} 2$ confidential helpline. Dickins repeated her concerns a month later in her Personal Development Review. Her employer referred her to occupational health; however, before the occupational health appointment took place, she suffered a breakdown. She was signed off by her doctor as unfit to work due to anxiety and depression and remained sick until her employment was terminated. The Court of Appeal held that $\mathrm{O} 2$ was liable for the stress related psychiatric injury that Dickins suffered.

The Court of Appeal in Dickins had made changes to the tests that plaintiff must overcome in relation to reasonable foreseeability, breach and causation. As observed in Dickins, the claimant had complained about the stress of her job and voiced out to her superior officer that she found it difficult to cope with her job and her concern on becoming ill due to her stress at work. On the basis of these facts, the court held that the claimant's psychiatric injury was held to be reasonably foreseeable from the point at which she requested a

46 (2008) EWCA Civ 1144. 
sabbatical and that there was sufficient warning of the risk of harm to her health. ${ }^{47}$

Earlier decisions show that an employer would not be liable for any injury that results from the first breakdown to a claimant, perhaps since the employer would not normally foresee such injury or breakdown. Thus, it is more onerous for a claimant who had not previously suffered any breakdowns to succeed in their stress claims. In Dickins, the court was of the view that it was not sufficient for the employer to discharge their duty by referring the claimant, Dickins to their helpline for confidential counselling especially because Dickins was complaining of severe stress hence suggesting that counselling was insufficient. The employer should have done more for the claimant, pending an urgent investigation by occupational health. ${ }^{48}$

Although in an earlier case, for instance in Hatton, an employer who provided a confidential advice and counselling service was unlikely to be in breach of duty, it seems that after Dickins, the employer cannot discharge their duty of care just by providing an employee, a confidential helpline. Hence, in future cases, employers will be under a duty to use some 'managerial intervention' and do more than simply refer their employees to a helpline when they are notified of the employees suffering from severe stress. ${ }^{49}$

It is worth noting that counselling for employees is a preventive measure which allows an employer, through the assistance of the qualified counsellors to assess the situation faced by their employees and allows for intervention. The current scenarios that are faced by many employees are worrying; employers would penalize or dismiss their employees who are unable to focus due to the overloaded demanding tasks placed upon them instead of helping them. The employers owe a duty towards their employees to provide the necessary support of counselling or psycho-emotional assistance to restore the well-being of the employees. The unnecessary burdens and workload placed upon the employees may results in anxiety, stress and depression which will all lead to psychiatric illness. As observed in the

\footnotetext{
47 (2008) EWCA Civ 1144.

48 (2008) EWCA Civ 1144.

49 Emma Costin,"landmark judgment on stress claims in dickens," accessed October5, 2021, https://www.simpsonmillar.co.uk/news/landmarkjudgment-on-stress-claims-in-dickins-v-o2-plc-290.
} 
discussion above, teachers and lecturers have to continue to work at home, as a result of spill over of the excessive tasks. Work related psychological illness such as burnt out, acute anxiety, depression and other mental health issues from the excessive job demand, job loss or job transfer or fear of demotion can lead to mental health issues if not managed properly.

\section{The Islamic Perspective}

Prophet Muhammad (PBUH) stated, "you should treat your servants well and should be considerate to them. You should not hurt them, for you should realise that they too have sensitive hearts like you. If hurt, their hearts get sore and grieved, and, if you treat them well, their faces glow to pleasure. Why, therefore, should you not be decent and kind with them"s0.

Unlike common law or statutory law which are human tailored and are susceptible to change with the variation of time and place, the Islamic approach of this subject matter is based on divine revelation, thereby subjecting the parties to divine obligation which can neither be curtailed, abrogated or disregarded ${ }^{51}$. The most striking characteristic

50 Kanz-ul-Ummal; quoted by Hakim Mohammed Said (ed) “The employer and employee - Islamic Concept, (Karachi, Dar al-Fikr Al-Islami, 1989), 55.

In Bukhari Vol.1 the Prophet (s.a.w.) was quoted as saying "Those working under you are your brothers. God has made those who serve you subservient to you. It, therefore, behoves that the person who employs a brother should give the latter to eat out of his own food and to clothe him from own wardrobe. And they should not be burdened with tasks beyond their powers and if such a burden has been thrown on their shoulders, then you should help them". In another tradition, Abu Huraira reported Allah's messenger as saying "A Muslim is the brother of a Muslim. He neither oppresses him nor humiliates him nor look down upon him. The piety is here, (and while saying so) he pointed towards his chest trice. It is a serious evil for a Muslim that he should look down upon his brother Muslim. All things of a Muslim are inviolable for his brother in faith, his blood, his wealth and his honour" Sahih Muslim Vol IV translated by Abdul Hamid Siddqi (New Delhi: Kitab Bhavan, 1978) 1361.

51 The Shari'ah is divine laws preceding the Islamic states, controlling the Islamic society. The objective of these laws are to provide guidance to the right path and defining the rights and duties. It is designed for all times 
of the Shari ${ }^{\prime} a h$ is its comprehensiveness and everlasting feature. It covers every department of life. ${ }^{52}$ Generally, it deals with two broad aspects of regulations; (a) a set of law's dealing with man's duties towards Allah (s.w.t.); and (b) law's governing human relations.

Its injunctions are however, often broad and flexible and are usually confined in laying down foundational rules. Notwithstanding the general character of its provisions and sometimes being unable to form a law based exactly from the words of the Creator, it can be seen that Islamic legislation has always managed to conform to the spirit of the al-Qur'an and the traditions of the Prophet (s.a.w.). A Muslim employer would therefore submit to this single will of Allah (s.w.t) paying careful attention to its numerous reminders of conforming to kindness and good character towards his employees, which would include avoiding psychiatric injury towards the workers.

In a two-step approach below, it will be firstly seen that in Islam, a person who seeks the bounty of Allah through hard work is most highly praised and secondly, be that as it may, this by no means allows employers to trample on the work ethics advocated in the Quran and Sunnah, for their personal advantage, at the expense of their workers' mental health.

\section{Work in Islam}

In an embracing concept of unity, worship and work are also correlated. It also leads to one path namely the path of Allah (s.w.t) and His pleasure. Islam regards work as sacred where both employer and employed are expected to work together for the growth and the

and is universal in its application. The Muslim states are subordinate to the Qur'an. The State could not have recourse to any other source if the Shari'ah contains a ruling, thus it leaves little room for additional legislation. For example, in the Qur'an, 12:64, it is stated, "No change can there be in the words of Allah". The laws cannot be abrogated or withdrawn by the temporal ruler or human agency. "Those who do not judge by what God has sent down are the disbelievers, wrong-doers and evil-doers". See, Qur'an, 5:44-47.

52 Fateh M. Sandeela, "The Distinctive Features of Islamic Law,"2 Islamic and Comparative Law Quarterly,(1982), 81, 89. 
progress of human life, command justice and act fairly between one another to invoke the pleasure of Allah (s.w.t).

Allah instructs Muslims to persistently work hard for a living. The Qur'an in Surah al-Jumu'ah (62) : 10 provides, "when the prayer is finished, then may ye disperse through the land, and seek of the bounty of God". Again, "It is He who has made the earth manageable for you, so traverse ye through its tracts and enjoy the sustenance which he furnishes; but unto Him is the resurrection" ${ }^{53}$ And finally, "Every man receives only what he makes an effort for". ${ }^{54}$

These injunctions of the Qur'an are not merely theoretical, but their practical application is also seen by numerous examples from the history of Islam during the time of the Prophets (peace and blessing of Allah be upon them). Many Prophets had worked hard to earn their livelihood.

Abu Burdah bin Dinar narrated that the Prophet Muhammad (s.a.w.) said "The best income is from a blessed sale (transaction) and what one earns by his hands". ${ }^{55}$ It has been reported on the authority of Abdullah bin Abbas that the Prophet (s.a.w.) has said: "Whoever spends a night while he is exhausted because of the day's labour his (sins) will be forgiven". ${ }^{56}$

From these traditions, it can be seen that seeking gainful employment is strongly encouraged in Islam and has been equated to ' ibadah (worship or divine service) ${ }^{57}$ just as much as praying. Islam places high importance on its people to attain jobs and work hard for an honest living because the income from these earnings will be blessed indeed $^{58}$. In other words, the lawful acquisition of wealth in order to

53 Qur'an,67:15.

54 Qur'an, 53:39.

55 Imam Ahmad, "Musnad", Vol 3, 466 and Vol. 4, 141.

56 At-Tabarani, "Tafsir al-Bayan".

57 'Ibadah denotes submissiveness and veneration tendered to the Divine Being. Worship comprises of resignation, submissiveness and humbleness. It is not merely confined to the saying prayers in love and fear of God, being patient with God's judgements, having trust in God, believing in the His Prophets, giving charity, fasting, pilgrimage, recital of the Qur'an, but covers a much wider concept. This includes working for himself and his family in pursuit of a legitimate livelihood.

58 As human beings, man and woman are equally having the same right and obligation. Thus, women are equally allowed to engage in lawful 
provide a means of personal and family livelihood is not only obligatory but also worthy of religious merits. ${ }^{59}$

Suffice it to be stated here that Islam not only respects those who are engaged in work, but it also promises rewards for it in this world and in the Hereafter. Work is regarded as a sacred deed in Islam commended by Allah (s.w.t).

\section{Employer-Employee Relationship and Injunctions against Ill- Treatment}

Unlike the common law where the employer is superior while the workers are subservient, in Islam the relationship between the employer and worker is a partnership. It is not a relationship of the superior and subordinate. ${ }^{60}$

The relationship between the employer and the employee is based on the concept of brotherhood. An employer should treat their workers with sensitivity and compassion. The Prophet (s.a.w.) was quoted as saying "those who serve you have been made by God subservient to you. It, therefore, connotes that the person who employs a brother should give the latter to eat out of his own food and to clothe him from own wardrobe. And they should not be burdened with tasks

employment provided that they should maintain the Shari'ah instruction - preserve modesty and wear proper attires. Women's right in engaging in the lawful employment was based on the verse in the Qur'an, 4:32. Furthermore, during the time of Prophet Muhammad (s.a.w.) many women used to work to support one's own self and the family and this was not objected to by the Prophet (s.a.w.). It was reported by Jaber that the Prophet (s.a.w.) permitted a woman who had been divorced, to visit her garden and take fruit of her palm trees. (Muslim).

59 Man had been ordained to engage in decent livelihood. Allah (s.w.t.) mentioned in the Qur'an, 53:39, that "Man can have nothing but what he strives for".

60 C.G.Weeramantry Islamic Jurisprudence: An Introductional Perspective (Basingstoke: Macmillan Press, 1988), 63. Superiority of one man over another is only on the basis of God-consciousness, purity in character and high morals. See for example the Qur'an, 49:13, "O Mankind We created you from a single pair of a male and a female and made you into nations and tribes, that ye may know each other. Verily the most honoured of you in the sight of Allah is he who is the most righteous of you. And Allah has full knowledge and is well-acquainted with all things". 
beyond their power and if such a burden has been thrown on their shoulders, then you should help them". ${ }^{61}$ Thus it follows, in light of the tradition that employers should be considerate, just and kind towards the workers and they should be forgiving and compassionate. The Qur'an (Surah Al-Naml (27): 27) states in reference to Prophet Shu'aib's employment of Prophet Moses while at his house. Prophet Shu'aib said; "I do not wish to put you to hardship. Insha Allah you will find me among the righteous persons".

The Prophet Muhammad (s.a.w.) specifically instructed as follows "just as you treat those near and dear to you, so should you treat those who are your equals by virtue of being human beings and not beneath you. As your hearts throb, so do theirs. See you not that I freed Zaid bin Harris and married him to the daughter of my paternal aunt; that I appointed Bilal as the caller for prayers; since he is our brother. You have been seeing that Anas has been serving me, but I do not look down with scorn upon him. If he does not do any job or fails to do it, I do not ask him why he failed to do this or that". ${ }^{62}$ The Prophet (s.a.w.) further stated, "you should treat your servants well and should be considerate to them. You should not hurt them, for you should realise that they too have sensitive hearts like you. If hurt, their hearts get sore and grieved, and, if you treat them well, their faces glow to pleasure. Why, therefore, should you not be decent and kind with them". The above ruling is based on the commandment from Allah (s.w.t.) which requires the believers to stand fast in adhering to justice and equality. Allah (s.w.t.) stated, "You who believe, stand fast before God as witness for truth and fair play" "63. In another verse, Allah (s.w.t.) stated, "be just, that is nearest to heedfulness. ${ }^{64}$

In another tradition, the Prophet (s.a.w.) warned for neglecting the fair treatment to the worker. He was quoted as saying, "be careful about those who depend on you. Treat them mildly. An owner, who

\footnotetext{
61 Al Bukhari Vol. 1. Cited in Hakim Mohammed Said, above at note 1,51.

62 Al-Adab Al-Mufrad; Kanz-ul-ummal'; cited in Hakim Mohammed Said, above at note 1,54 .

63 Qur'an, 4:135.

64 Qur'an, 5:8., Qur'an, 57:25, “We sent our messenger with clear sign, and sent down with them the book and the balance so that men may conduct themselves with justice".
} 
mistreats his servant, shall never enter the portals of paradise" ${ }^{65}$. One day the Prophet (s.a.w.) was approached by a companion and asked the Prophet (s.a.w.) "Prophet of God, how many times should I forgive my servants? The Prophet (s.a.w.) sat quietly and contemplatively and the companion asked the same question again. He finally replied in a very soft and yet saddened tone: Why are you asking about the number of times? If your servants miscarry your orders or are guilty of grievous wrong seventy times each day, you should forgive them for an equivalent number, for they are your brothers". ${ }^{66}$

\section{Protection for Employees from Physical and Psychiatric Injury under the Islamic Law}

As discussed earlier, it can be clearly observed that the Quran and Sunnah seek to protect a worker from exploitation and abuse from physical harm as well as psychiatric injury. When the Prophet (s.a.w) spoke about sensitive hearts, hearts getting sore and grief, hurt feelings, faces glowing etc, it relates to the emotion of a person that may amount to psychiatric injury, if subject to abuse and if the person concern is unreasonably overburdened with work. A man devoid of feelings and sympathy towards others cannot be a Muslim by his actions.

This is even reflected in Article XVII of the Universal Islamic Declaration of Human Rights ${ }^{67}$, that proclaimed; "Islam honours work

65 Kanz-ul-ummal Vol. 5, 18; Majma-uz-zawaid Vol. 4, 236. The Prophet (s.a.w.) was also quoted as saying that; "the best among you is the one who treats his servants with kindness and charity" see Kanz-ul-ummual vol.5, 18; Majma-uz-zawaid vol. 4, 337. The worker should not be overburdened with work. Qur'an, 2:286., said: "On no soul does Allah place a burden greater than it can bear."

66 Tirmizi; quoted by Hakim Muhammed Said, above at note 1, 55. The Prophet (s.a.w.) said "The owners who mete out evil treatment towards their servants shall find the gateway of paradise shut to their faces".

67 Islamic Council, 19 September 1981, "The Muslim jurist gathered at the International Islamic Conference held in Paris on the15th September 1981 and proclaimed the Universal Islamic Declaration of Human Rights, which was supported on the basis of specific Islamic texts." The preamble of the declaration proclaims "human rights decreed by the divine law aim at conferring dignity and honour on mankind and are designed to eliminate oppression and injustice". These rights can "neither be curtailed, 
and the worker's and enjoins Muslims not only to treat the worker justly but also generously. He is not only to be paid his earned wages promptly, but is also entitled to adequate rest and leisure". In short, workers in Islam are highly regarded and are to be well treated ${ }^{68}$.

From the foregoing discussion, it has been observed that Islam sets out general guidelines on the employer and employee relationship where parties should transact their business with kindness, courtesy, amity and mutual co-operation. Neither the employer nor the worker enjoys any innate moral superiority. In view of the wide coverage of injunctions of the Islamic Shari 'ah, it does not lack in the guiding principles in respect of labour welfare. It is submitted that Islam accords full protection to the rights of the worker's and requires employers to adhere to the established principles of justice and equality.

\section{CONCLUSION}

It should be borne in mind that under the Islamic Law, the welfare of employees is a paramount factor. An employer should take steps to ensure that the employees are protected not only from physical injuries but also, psychological injuries or illness stemming from the nature of excessive or unreasonable workload. Taking care of the welfare of employees is considered as an act of worship (ibadah). Islam has a set of basic rules and regulations for employer and employee to run their affairs. In Islamic history employees were treated as the creator and value of wealth in the marketplace. Employees are placed at the centre of economic activities and without them there will be no value or wealth creation. ${ }^{69}$ Ibn Khaldun argued that "labour belongs to the things that constitute capital" and that "profits are value derived from

abrogated nor disregarded by authorities or other institutions, nor can they be surrendered or alienated".

68 Prophet Muhammad (s.a.w.) was reported as saying; "These servants of yours are your brothers. So, treat them well. Take their help in such work which you cannot do yourself. And help them in the work which they cannot do by themselves" Sahih Bukhari Kitab al-ItqaVol.II (Cairo, 1304 A.H.), 60 .

69 Prophet Muhammad (s.a.w.), "These servants of yours are your brothers". 
labour". ${ }^{70}$ The social welfare aspect of employment relations in Islam is visible in the workplace logic of ihsan (goodness and generosity of employee relation). ${ }^{71}$ In Islam, ethical considerations may take precedence over financial considerations in employment relations. Long before trade union was in existence, Islam made a clear path forward of what employees' rights are and how they were to be fulfilled. By fulfilling these rights, one serve Allah (s.w.t) because these rights are conferred by Allah (s.w.t) Himself. The Prophet (s.a.w.) infused justice, love and dignity in all those around him and spread the power of brotherhood. He ordained employers to respect their employees on the footing of brotherhood. In the context of employment, there should not be any room for exploitation and abuse upon an employee. Thus, it naturally follows that an employee should not be overburdened and overwhelmed with work. Most of the cases involving psychiatric injury emanates from stress-at-work.

The law on psychiatric injury, a by-product of the law of negligence has evolved over a long span of time. The law provides remedies for one who suffered from psychiatric injury due to the negligence of another. With the increasing number of cases in relation to employees, the decision in Dickins has brought changes to claim by employees who suffer from psychiatric injury. Dickins follows the clear guidance set out by the Court of Appeal in Hatton which set out the core principles on claim for a stress related injury by employee. The threshold test in stress claim has to be whether the employer could have reasonably foreseen the problem. Dickins however went one step further, making it easier for employees to successfully make a claim against their employer for psychiatric injuries caused by occupational stress. Therefore, both employers and employees should take note of the changes to the legal tests outlined in Dickins. In particular, employees suffering stress and contemplating making a claim against their employer would be advised to notify their employer of their problems as soon as possible in order to show that any future injuries they suffer could have been anticipated.

Most of the cases presented in the above study shared similar perspective which illustrated individuals' tendency to be overly

70 Jawad Syed and Abbas Ali, "Principles of Employment Relations in Islam: A normative View,"emerald insight32, no.5(August2010):454-469, DOI 10.1108/01425451011061630

71 Syed and Ali, "Principles of Employment Relations in Islam", 454-469 
stressed by the employers' expectations and work demand. Evidently, the inability to cope the overwhelming demand interfere with their focus at work. Keeping the employees at work when they are 'not fit' will impede the process to recover fully from excessive stress that could lead to psychiatric injury. Workers must be given the support with ample time and space to get proper mental health professional help so that it allows them to focus on recovering just like any other physical injuries.

Employers would be advised to review their policies in relation to referring employees to confidential counselling, help-lines or occupational health when they are notified that an employee is suffering from stress. If an employee is suffering from severe stress, employers should also strongly consider whether further managerial intervention is necessary. It is to be borne in mind that wellness of employees covers all aspect of physical, mental, social emotional and moral-spiritual. ${ }^{72}$ In order for employers to meet their duty of care to their employees, it is important that the tasks given to the employees do not cause distortion to their wellness, causing them to suffer from psychiatric injury.

72 IIUM has for many years organized programmes which caters to the wellness of the employees; to name a few-Fi Zilal al Quran, Monthly reading of Thya Ulul Al Din. 